\title{
Development of Web-Based Learning Media in The Research Methodology Course in The Department of Electrical Engineering Medan State University
}

\author{
Abdul Muin Sibuea ${ }^{1}$, Mohammad Amin², and Joni Syafrin Rambey ${ }^{3}$ \\ Fakultas Teknik, Universitas Negeri Medan ${ }^{1,2,3}$
}

\begin{abstract}
This research aims to determine the development of web-based media in the Research Methodology course in the Department of Electrical Engineering Education, Faculty of Engineering, Medan State University. The type of research was research and development (R\&D) refers to Borg and Gall, and combines with learning development model of Dick and Carey. The subjects in this study were 47 students of the Department of Electrical Engineering Education class of 2017. The instrument used was in the form of a questionnaire and consisted of 4 instruments, namely validation instruments for media experts, validation instruments for design experts, validation instruments for material experts, and product trial instruments for students. The validation instrument for media experts contains 27 indicators that are classified into 5 aspects of assessment namely Guidelines and Information, Web Operations, Media Systematics, Media Aesthetics, and Principles of Web Form Variety. The validation instrument for design experts contains 18 indicators that are classified into 5 aspects of assessment, namely Appropriateness of Design, Attractiveness of Physical Appearance, Format Suitability, Presentation with Target Characteristics, and Clarity of Material Exposure. The validation instrument for material experts contains 20 indicators that are classified into 2 aspects namely Content Feasibility and Presentation Feasibility. The product trial instrument for students contains 33 indicators that are classified into 5 aspects, namely Guidelines and Information, Media Materials, Evaluations, Design and Facilities of Media and Pedagogical Effects. Research data obtained from questionnaires that have been filled out by media experts, design experts, material experts and students are formulated into scores, which are then interpreted into assessment criteria consisting of Bad, Poor, Doubtful, Good, and Very Good.
\end{abstract}

Keywords: Media Learning, Web Learning, Web-Based

\section{Introduction}

The impact of advances in information and communication technology has now changed the way people look and act in spending time working and overcoming their problems. The forms of developments and changes in information technology basically change people's activities in the real world into cyberspace activities. Many other forms of change occur in the joints of people's lives brought about by the development and advancement of technology and information (IT), not least in the world of education. The impact of advances in information and communication 
technology (ICT) in the world of education is extraordinary. Various learning models using computers such as: e-learning (electronic learning), Computer Assisted Instruction (CAI), Computer Based Instruction (CBI), and e-teaching (electronic teaching) are very possible to facilitate the development of the world of education. This learning model allows educators and students to find their learning materials directly from sites on the internet through computers as learning tools.

The world of education is among those who have benefited greatly from the progress of ICT because it has gained tremendous benefits both in terms of learning models and the use of learning media. The use of computer-based learning media is considered to be more optimal to be used in supporting education today because with learning media students can learn and analyze teaching materials themselves whenever and wherever they are without having to wait for the presence of educators to explain these teaching materials.

Academic is often directed as the completeness in the completion of a study program at a tertiary institution, so the initial motivation is more to the practical needs of study programs at tertiary institutions than the needs of students in developing or discovering something new. The results are certainly very little that can be used as a contribution to the development of science. However, it cannot be denied that academic research has given students the basics of experience in the direction of developing research capabilities.

According to Sugiyono [1] through research, students can use the results to understand, solve and anticipate problems. Understanding means clarifying an unknown problem or information and then knowing, solving means minimizing or eliminating the problem, and anticipating means trying to prevent the problem from happening.

To provide students with an adequate understanding of the importance of research work, one of the courses they undertake at the Faculty of Engineering, Medan State University is Research Methodology. Besides because academic research (thesis) is one of the obligations of students in completing their studies in tertiary institutions, it is also hoped that it can be used as a basis for research experience.

Research Methodology courses provide a large provision for students to be able to think and move carefully, precisely, correctly, using a common and clear systematics. In addition, the content presented from research cannot be subjective, emotional, revealing conjecture, prejudice and without facts. According to previous research conducted by the scientific method is based on scientific features that are rational, empirical and systematic. Some problems that arise in the Research Methodology course are the lack of interest and attention of students in the course, so we need a method or a creative media that is expected to increase student interest and motivation to study in the research methodology course. In fact, learning of Research Methodology courses conducted by lecturers is still in the form of conventional learning. As a result, students' learning outcomes are not in line with expectations. This is evidenced by the data obtained from the students' even semester grades for the academic year 2017/2018, the average final grade for the Research Methodology course is still quite sufficient and has not shown a good category (Archive of the final semester scores for the academic year 2017/2018, Department of PTE, UNIMED).

The main problem in learning Research Methodology is the use of learning methods or models in conveying subject matter appropriately, which fulfills the contents of the order of values, so that it can be internalized within students and implements the nature of value education in daily life that does not meet expectations as desired. This relates to the community's criticism of the 
Research Methodology learning material that is not loaded with practical values but is merely theoretical or rote for the sake of obtaining high grades or GPA. Learning methods in teaching and learning (PBM) seem very rigid, less flexible, less democratic, and lecturers tend to be more dominant in one-way method.

To deal with community criticism above, there is an effective and efficient learning media as an alternative, namely by using the web as a learning medium. It cannot be denied that the existence of computer-based learning media has become an important part in the world of education today. Computer-based media in the development of instructional media is often referred to as learning multimedia because the ability of computer media to convey messages through visual media, audio media, text in the form of recording or broadcast media. This technology is expected to be able to help the education process in general and specifically so that what you want to achieve through the education process can be obtained properly.

This discussion emphasizes the validation of instruments used in collecting data, namely expert validation including validation of material experts, media experts, and design experts as well as product trials to students.

\section{Methods}

The research method used in this research is research and development or research and development (R\&D). According to Borg and Gall [2] research development is a research method used to develop or validate products used in education and learning. Development research aims to create a product to be used in the learning process. The product produced in this research is in the form of website-based e-learning learning media. The research and development model used in this study refers to the research model developed by Borg \& Gall [2] by carrying out the research and development steps as in Figure 1.

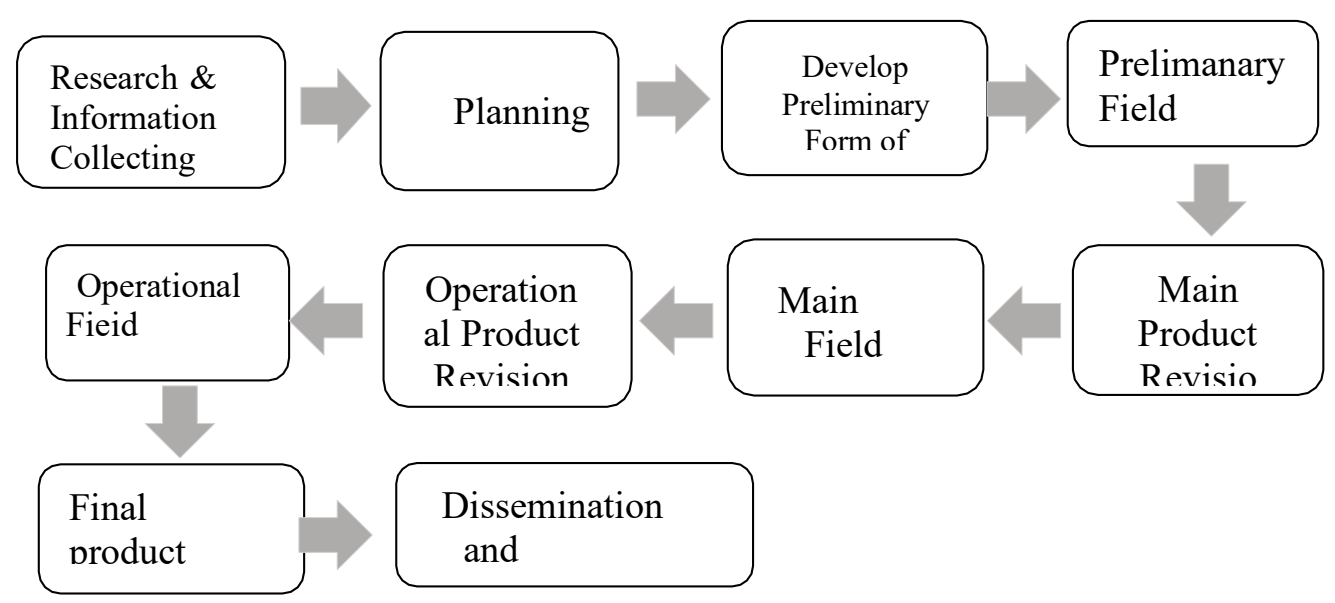

Figure 1. Development Research Step 
Systematic research in developing web-based learning media in Research Methodology courses is shown in Figure 2.

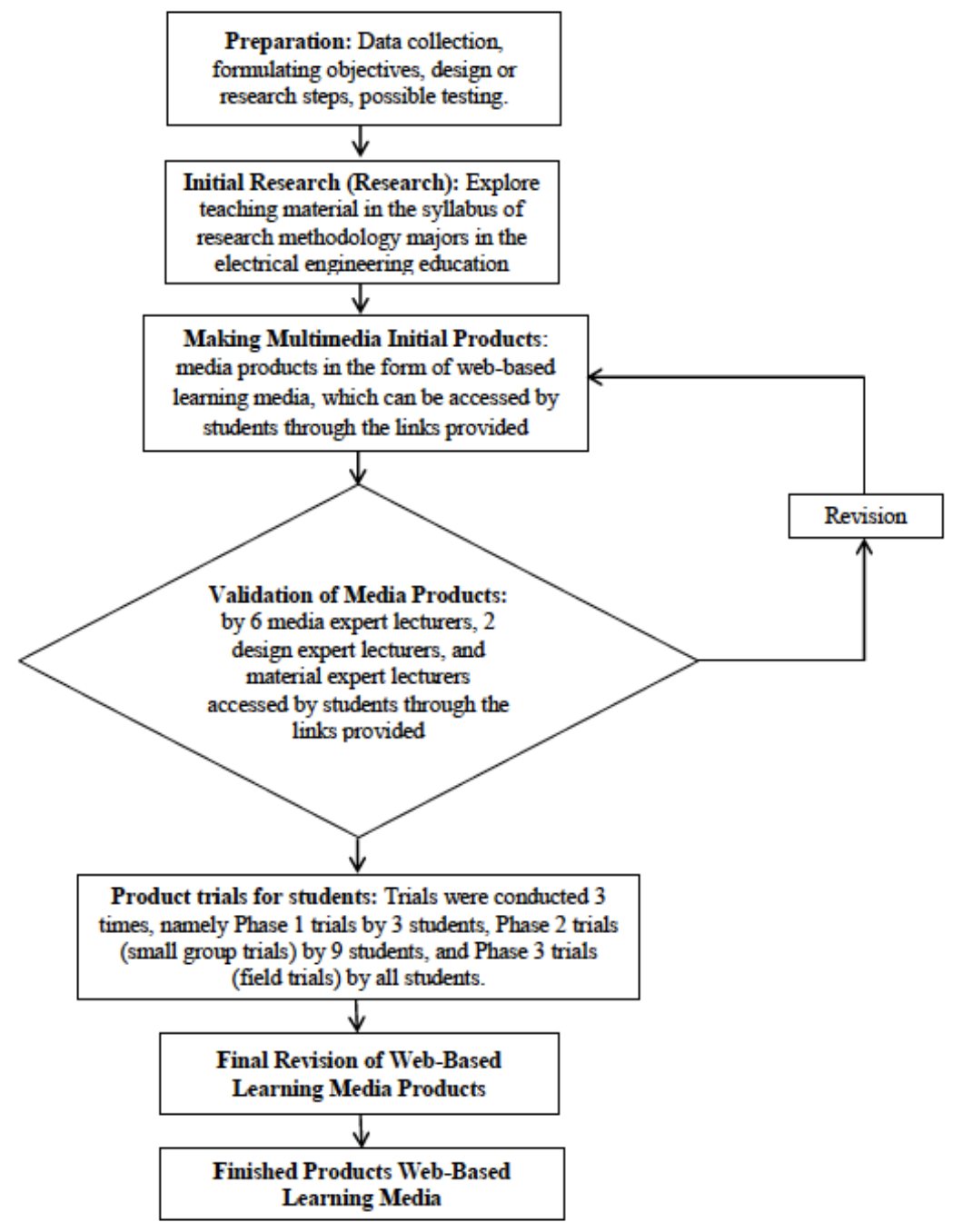

Figure 2. Systematic research

\section{Results and Discussion}

This study uses a research and development approach (Research and Development) using three 
stages, namely (1) a preliminary study, (2) planning and preparation of web-based learning media and (3) field testing of instructional media developed. Following are the results obtained from each of the stages.

\section{Description of Preliminary Study Results}

The process of implementing web-based learning media development is carried out in stages. In the initial stages of research and development is to determine the courses to be developed. The next step is to conduct preliminary research in accordance with the syllabus. This study aims to obtain the data needs needed by lecturers and students in the lecture process.

The preliminary study aims to determine the need for developing web-based learning media in the Research Methodology course. The activity carried out at this stage was to collect data about the learning process that had been carried out by observation to the university where the research was conducted.

\section{Description of Test Result Data}

The trial was carried out in 4 stages, namely: (1) evaluation of material experts, media experts, and design experts, (2) individual trials, (3) small group trials, and (4) field trials.

\section{a. Expert Validation Results}

Product validation aims to find out the opinions of experts namely material experts, media experts, and learning design experts about the accuracy of the design, aspects of learning and the truth of the contents as well as the learning design.

\section{i) Material Expert Validation Results}

Material expert validation on the development of web-based learning media was conducted by two material expert lecturers namely: (1) Dr. Arif Rahman, M.Pd and (2) Drs. Dadang Mulyana, M.Pd. The assessment is carried out to obtain information that is used to improve the quality of web-based learning media in the Research Methodology course. The results of validation in the form of an assessment score of the learning media components of this research methodology on the quality of learning material can be seen in Table 1 .

Table 1. Material Expert Rating Score

\begin{tabular}{|c|c|c|c|c|c|c|c|}
\hline \multirow[b]{2}{*}{ No } & \multirow{2}{*}{ Aspect } & \multirow{2}{*}{$\frac{\text { Reviewer }}{1}$} & \multirow{2}{*}{$\begin{array}{c}\text { Total Score } \\
2 \\
\end{array}$} & \multirow[t]{2}{*}{ Average } & \multicolumn{2}{|c|}{ Percentage $(\%)$} & \multirow[t]{2}{*}{ Information } \\
\hline & & & & & & & \\
\hline 1 & Content Feasibility & 51 & 48 & 99 & 8,9 & 99 & Very Good \\
\hline 2 & $\begin{array}{l}\text { Presentation } \\
\text { Feasibility }\end{array}$ & 45 & 44 & 89 & 9,8 & 89 & Very Good \\
\hline & Average Total Score & & & 9,4 & & & Very Good \\
\hline
\end{tabular}

Based on expert assessment of web-based learning media material on Research Methodology courses worth 9,4 that fits the criteria very well (94\%) that means "fit for use". From the results of the material expert validation above we can see the quality of the contents and the quality of the presentation in this criterion is very good. 


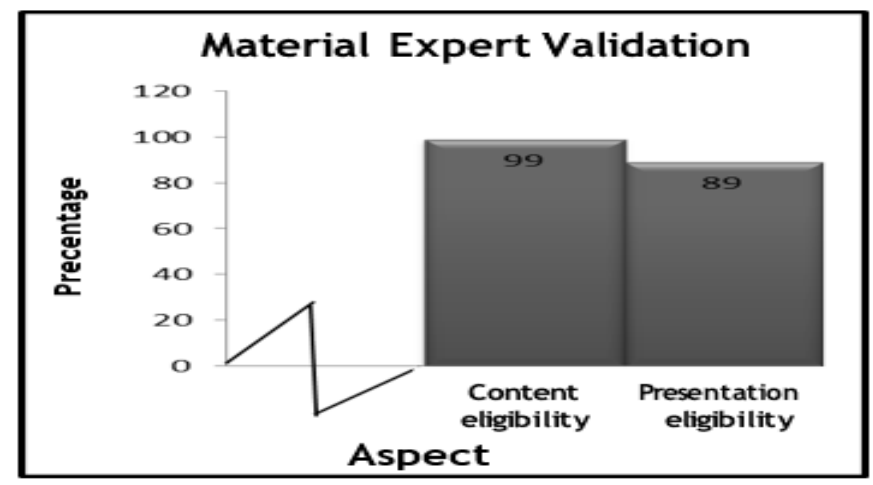

Figure 3. Total Number of Average Diagram of Material Expert Rating Results

\section{Media Expert Validation Results}

The validation of learning media experts was carried out by two instructors of instructional media experts namely: (1) Dr. Agus Junaidi, ST., MT. and (2) Uli Basa Sidabutar, S.Kom., M.Pd. Learning media experts validate the product aspects of instructional media including on the start page, media layout, use of letters, typography of letters, and picture illustrations. Validation results in the form of scores on the assessment of web-based learning media components in the Research Methodology course on the quality of instructional media can be seen in Table 2 .

Table 2. Media Expert Ratings

\begin{tabular}{|c|c|c|c|c|c|c|c|}
\hline \multirow{2}{*}{ No } & \multirow{2}{*}{ Aspect } & \multicolumn{2}{|c|}{ Reviewer } & \multirow{2}{*}{$\begin{array}{l}\text { Total } \\
\text { Score }\end{array}$} & \multirow{2}{*}{$\begin{array}{l}\text { Ave } \\
\text { rage }\end{array}$} & \multirow{2}{*}{$\begin{array}{c}\text { Percentage } \\
(\%)\end{array}$} & \multirow[t]{2}{*}{ Information } \\
\hline & & 1 & 2 & & & & \\
\hline 1 & Information Guide & 13 & 14 & 27 & 9,0 & 89,9 & Very Good \\
\hline 2 & Web Operational & 49 & 40 & 84 & 8,9 & 89,0 & Very Good \\
\hline 3 & $\begin{array}{l}\text { Systematics of } \\
\text { Media }\end{array}$ & 14 & 13 & 27 & 9,0 & 89,9 & Very Good \\
\hline 4 & Media Aesthetics & 20 & 15 & 35 & 8,8 & 87,5 & Very Good \\
\hline 5 & $\begin{array}{l}\text { Principles of Web } \\
\text { Design Conformity }\end{array}$ & 34 & 28 & 62 & 8,8 & 88,5 & Very Good \\
\hline vera & Total Score & & & & 8,9 & 88,96 & Sangat Baik \\
\hline
\end{tabular}

According to learning media experts, the quality of web-based learning media from aspects of information guidance, web operations, media systematics, media aesthetics, and web design principles is 8.9 within the range of the "feasible testing" criteria. The percentage of total scores from learning media experts was $88.96 \%$ that was included in the "very good" category. 


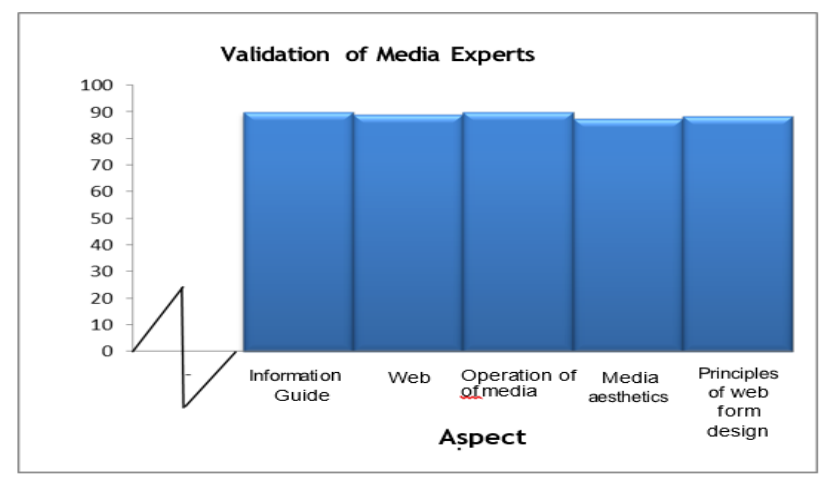

Figure 4. Diagram of Average Score Score Results of Media Expert Ratings

\section{1) Design Expert Validation Results}

The validation of learning design experts was carried out by two instructors of learning design experts. Learning design experts validate the product aspects of learning design including aspects of the attractiveness of physical appearance consisting of the attractiveness of colors on the media, proportional (layout of text and images), aspects of the accuracy of the use of design consisting of the accuracy of topic selection, compatibility of material with indicators, aspects format suitability, aspects of the presentation with target characteristics consisting of clarity of material description in the media, clarity of the examples given in the learning media, use of new information, aspects of clarity of media instructions consisting of the use of instructions on instructional media, explanation of the terms in the media, use of texts, the ease of learning media, the clarity of the material exposure aspect consisting of the material presented, the relevant material, and the suitability aspect of the evaluation with the material consisting of the material presented, the relevant material, and the evaluation aspect of the suitability of the material consisting of exercises and questions. The results of the validation take the form of a score assessment of web-based learning media components in the Research Methodology course. According to the instructional design expert the quality of the developed learning media is good and worth testing, the assessment score can be seen in Table 3.

Table 3. Design Expert Assessments

\begin{tabular}{clcccccc}
\hline \multirow{2}{*}{ No } & \multicolumn{1}{c}{ Aspect } & \multicolumn{2}{c}{ Reviewer } & $\begin{array}{c}\text { Total } \\
\text { Score }\end{array}$ & $\begin{array}{c}\text { Ave } \\
\text { rage }\end{array}$ & $\begin{array}{c}\text { Percentage } \\
(\%)\end{array}$ & Information \\
\cline { 2 - 6 } 2 & 1 & 2 & 54 & 9 & 90 & Very Good \\
2 & $\begin{array}{l}\text { Appropriate Usage } \\
\text { of Design } \\
\text { Physical }\end{array}$ & 25 & 20 & 45 & 9 & 90 & Very Good \\
3 & $\begin{array}{l}\text { Appearance } \\
\text { Format suitability }\end{array}$ & 5 & 4 & 9 & 9 & 90 & Very Good \\
4 & $\begin{array}{l}\text { Dishes with Target } \\
\text { Characteristics }\end{array}$ & 15 & 12 & 27 & 9 & 90 & Very Good \\
Clarity of Material & 15 & 12 & 27 & 9 & 90 & Very Good \\
\hline Averposure & Everage Total Score & & & 9 & 90 & Very Good \\
\hline
\end{tabular}


According to learning design experts that the quality of web-based learning media in the Research Methodology course is worth 9 which is within the range of very good criteria. The percentage of total scores from learning design experts is $90 \%$ that is included in the "very good" category. The result of the validation of the learning design expert is feasible to use without any revisions.

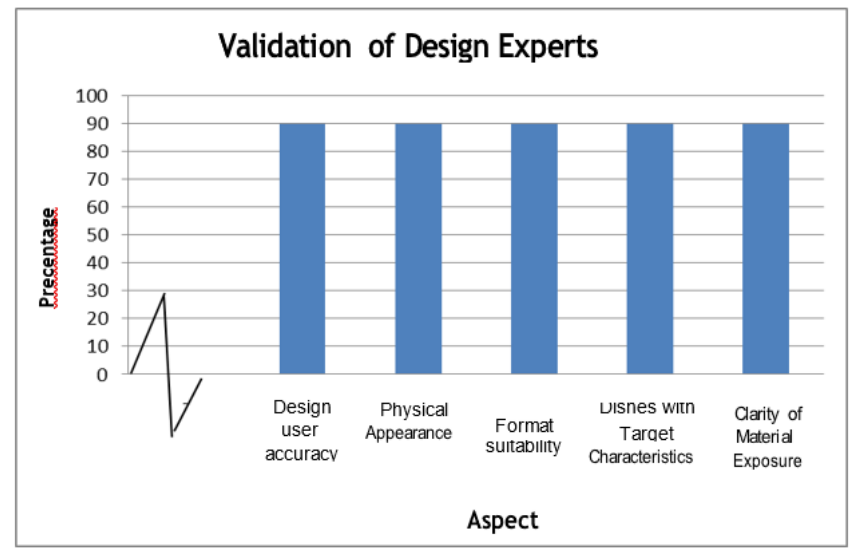

Figure 5. Diagram of Average Score Results

\section{a. Phase I Trial Results (Individual Trial)}

Individual trials were conducted at the Department of Electrical Engineering Education, Faculty of Engineering, Medan State University with 3 students consisting of 1 student having high achievement, 1 student having moderate achievement, and 1 student having low achievement. The purpose of this individual trial is carried out to identify deficiencies in learning products after being reviewed by experts. This trial evaluation and input is about guidance and information, media material, evaluation, design and media facilities and pedagogical effects. The results of individual phase I trials can be seen in Table 4.

Table 4. Results of the Phase I Individual Trial Questionnaire

\begin{tabular}{clrcccccc}
\hline \multirow{2}{*}{ No } & \multirow{2}{*}{ Aspect } & \multicolumn{3}{c}{ Student } & \multirow{2}{*}{$\begin{array}{c}\text { Total } \\
\text { Score }\end{array}$} & Average & $\begin{array}{c}\text { Percentage } \\
(\%)\end{array}$ & Information \\
\cline { 3 - 6 } & & $\mathrm{T}$ & $\mathrm{S}$ & $\mathrm{R}$ & & & \\
\hline 1 & Information Guide & 20 & 17 & 15 & 52 & 4.3 & 85 & VeryGood \\
2 & Media Material & 60 & 57 & 51 & 168 & 4.7 & 93 & Very Good \\
3 & Evaluation & 25 & 24 & 20 & 69 & 4.6 & 92 & Very Good \\
4 & Design Dan Facility & 35 & 33 & 27 & 95 & 4.5 & 90 & Very Good \\
5 & Pedagogical Effect & 25 & 24 & 22 & 71 & 4.7 & 95 & Very Good \\
\hline Average Total Score & & & & & 5 & 91 & Very Good \\
\hline
\end{tabular}




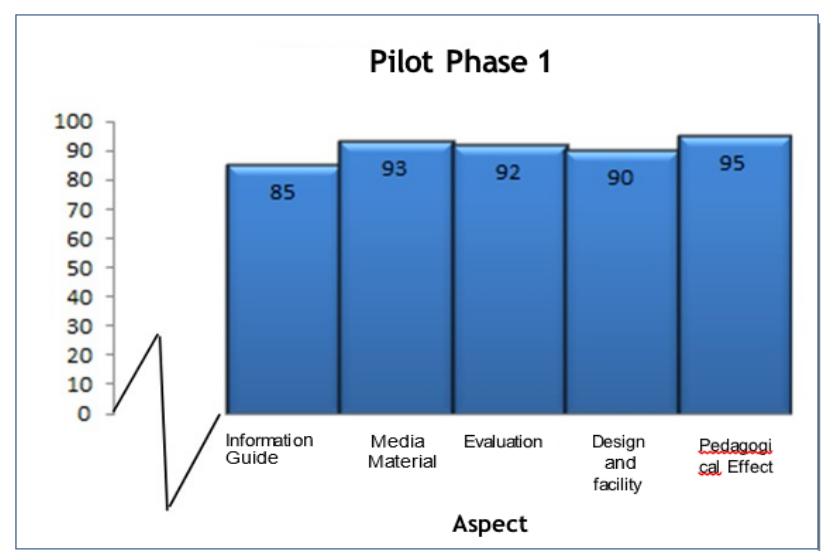

Figure 6. Diagram Percentage of Phase I Trial Scores

Student responses to individual trials at the Department of Electrical Engineering Education, Medan State University are shown in table 5.4 explained that the learning of web-based learning media from the aspects of information guidance, media material, evaluation, design and facilities and pedagogical effects were assessed overall, each including the criteria of "Very Good" ie with an average score of $91 \%$.

\section{b. Phase II Trial Results (Small Group Trials)}

A small group trial where web-based learning media was implemented to 9 students in the Department of Electrical Engineering Education, Medan State University, namely 3 highachieving students, 3 moderate-achieving students, and 3 low-achieving students. This small group trial data is used as initial experience before the product is tested on a large field. Data on the results of small group trials can be seen in the following Table 5 .

Table 5. Small Group Trial Results Questionnaire Data

\begin{tabular}{|c|c|c|c|c|c|c|c|c|}
\hline \multirow[b]{2}{*}{ No } & \multirow[b]{2}{*}{ Aspect } & \multicolumn{3}{|c|}{ Student } & \multirow{2}{*}{$\begin{array}{l}\text { Total } \\
\text { Score } \\
\end{array}$} & \multirow[t]{2}{*}{ Average } & \multirow{2}{*}{\multicolumn{2}{|c|}{$\begin{array}{l}\text { Percentage Inform ation } \\
(\%)\end{array}$}} \\
\hline & & $\mathbf{T}$ & $\mathbf{S}$ & $\mathbf{R}$ & & & & \\
\hline 1 & Information Guide & 57 & 52 & 51 & 160 & 4.5 & 80 & VeryGood \\
\hline 2 & Media Material & 171 & 168 & 155 & 494 & 4.6 & 80 & VeryGood \\
\hline 3 & Evaluation & 71 & 73 & 64 & 208 & 4.6 & 80 & VeryGood \\
\hline 4 & Design dan Facility & 102 & 101 & 90 & 293 & 4.7 & 80 & VeryGood \\
\hline 5 & Pedagogical Effect & 70 & 70 & 67 & 207 & 4.6 & 80 & VeryGood \\
\hline 10 & Total Score & & & & & 4.6 & 80 & VeryGood \\
\hline
\end{tabular}




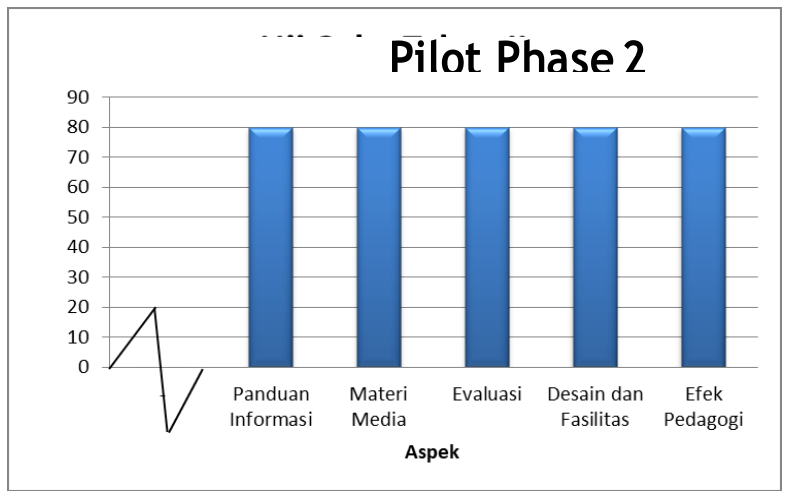

Figure 7. Percentage Diagram of Phase II

In table 5.5 above can be seen trials conducted in the Department of Electrical Engineering Education, UNIMED conducted by 9 students visible from the percentage total score percentage is " $80 \%$ " so that it can be said web-based learning media from the aspects of information guidance, media material, evaluation, design and facilities, and pedagogical effects are included in the "very good" criteria.

\section{c. Phase III Trial Results (Field Trials)}

Field trials are carried out after the implementation of individual trials and small group trials. The field trial was conducted at the Department of Electrical Engineering Education, Medan State University in the 2017 class of 47 students. Field trials produce data that will later measure the feasibility of the product being developed, and to find out the benefits of the product for its use. Field trial evaluation results can be seen in table 4.6.

Table 6. Data from Field Test Questionnaire Results

\begin{tabular}{clcccc}
\hline No & \multicolumn{1}{c}{ Aspect } & Total Score & Average & $\begin{array}{c}\text { Percentage } \\
(\%)\end{array}$ & Information \\
\hline 1 & Information Guide & 846 & 4.5 & 90 & Very Good \\
2 & Media Material & 2585 & 4.6 & 92 & Very Good \\
3 & Evaluation & 940 & 4.0 & 80 & Very Good \\
4 & Design dan Facility & 1410 & 4.3 & 85 & Very Good \\
5 & Pedagogical Effect & 1081 & 4.6 & 92 & Very Good \\
\hline Average Total Score & & 4.4 & 88 & Very Good \\
\hline
\end{tabular}




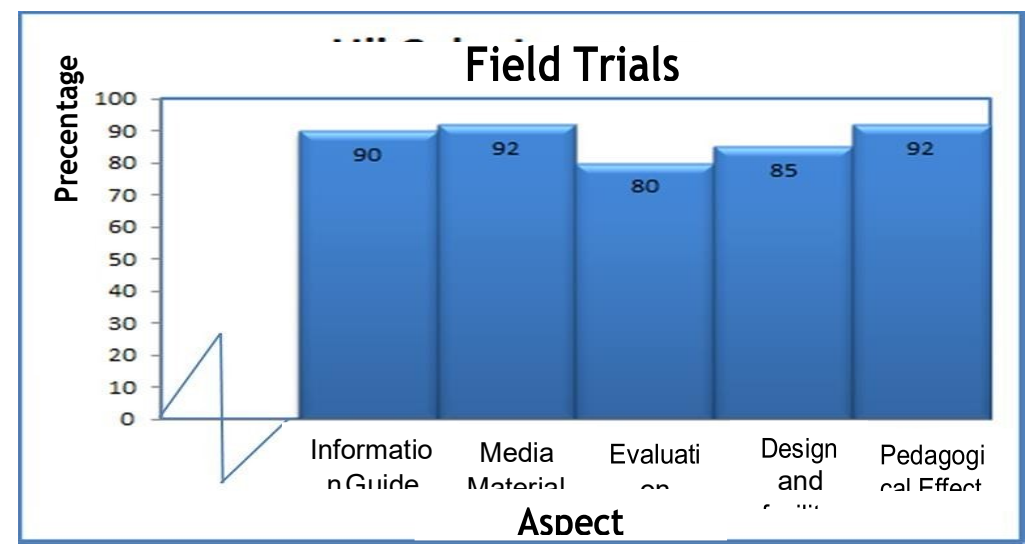

Figure 8. Diagram of Field Trial Results

Student learning outcomes in field trials in the Department of Electrical Engineering Education, Medan State University class of 2017 explained that web-based learning media from aspects of information guidance, media material, evaluation, design and facilities, and pedagogical effects were assessed as a whole each included in the "Very Good" category. Table 4.6 it can be seen that the total score percentage of all aspects is $88 \%$ so if it is included in the percentage category according to Sugiyono [1] then the validation of web-based learning media is categorized as "Very Good".

In the field trials conducted on 47 students in the Department of Electrical Engineering Education UNIMED in general students stated that web-based learning media was very amenable to use and there were no problems that had to be fixed, thus no revisions were made to the field trials. The results of an assessment of web-based learning media in the field trial of 47 students of the Department of Electrical Engineering Education, Medan State University in 2017 showed that the products developed were very good and suitable for use.

\section{Conclusion}

Based on the results and discussion of research and development of web-based learning media conducted, it can be concluded as follows: Web-based learning media for courses Research Methodology is feasible to use for the percentage of material expert validation $94 \%$ falls into the excellent category, media expert validation is $88.96 \%$ is in the very good category, and design expert validation is $90 \%$ in the very good category. For the first phase trial resulted in a percentage of $91 \%$ included in the excellent category, for the second phase trial resulted in a percentage of $80 \%$ included in the excellent category and for field trials to all students the percentage of $88 \%$ included in the excellent category. 


\section{Suggestion}

Based on the results of research and development of web-based learning media conducted, the following suggestions can be given:

1. It is recommended for lecturers to use web-based learning media to improve students' learning outcomes in the Research Methodology course.

2. Web-based learning media can be used as an example for lecturers in developing learning media.

\section{References}

[1] Sugiyono. Metode penelitian kuantitatif, kualitatif dan R\&D. Cet. XVIII. Bandung: Alfabeta, (2013).

[2] Borg, Walter R., and Gall, Meredith Darmein.: Educational Research: An Introduction.New York: Longman Inc (1983).

[3] Dick, W., Carey, L., \& Carey, J.O. . The Systematic Design of Instruction (6 $6^{\text {th }}$ ed.). New York: Allyn \& Bacon, Published by Allyn and Bacon, Boston, M.A (2005).

[4] Joyce, B., \& Weil, M. Models of Teaching. Englewood Cliffs, NJ.: Prentice Hall (1980). 